\title{
Use of the Aintree intubation catheter $\AA$ in a patient with an unexpected difficult airway
}

\section{[L'usage d'un Aintree intubation catheter ${ }^{\circledR}$ dans un cas d'intubation difficile} imprépue]

Andrew Zura MD, D. John Doyle MD PhD FRCPC, Marc Orlandi MD

Purpose: To present a case where the Aintree intubation catheter ${ }^{\circledR}(\mathrm{AIC})$ was used in conjunction with the Laryngeal Mask Airway ${ }^{\circledR}($ LMA $)$ and a fibreoptic bronchoscope $(F O B)$ in a patient with an unexpected difficult airway.

Clinical features: A 38-yr-old $90 \mathrm{~kg}$ man scheduled for nasal endoscopy with ethmoidectomy under general anesthesia was found, unexpectedly, to be difficult to intubate using both a Macintosh laryngoscope (\#4 blade) and a GlideScope ${ }^{\circledR}$ video laryngoscope despite having an airway examination that was unremarkable except for slightly decreased mouth opening and a large tongue. Intubation was achieved by inserting a size 5 disposable LMA into the upper airway, introducing a FOB into an AIC inserting the $\mathrm{FOB} / \mathrm{AIC}$ assembly into the trachea via the $L M A$, removing the LMA, and then passing a regular size $(7.5 \mathrm{~mm})$ endotracheal tube into the trachea over the AIC.

Conclusion: In this patient, the AIC provided an effective alternative to other methods for intubating through a regular LMA.

Objectif : Présenter un cas où le Aintree intubation catheter $\AA$ (AIC) $a$ été utilisé en conjonction avec le Laryngeal Mask Airway ${ }^{\circledR}$ (LMA) et un fibroscope bronchique (FOB) dans un cas d'intubation difficile imprévue.

Éléments cliniques : Un homme de 38 ans, pesant $90 \mathrm{~kg}$, devant subir une endoscopie nasale et une ethmoïdectomie sous anesthésie générale a été, de façon inattendue, difficile à intuber avec un laryngoscope Macintosh (lame 4) et un vidéo-laryngoscope GlideScope ${ }^{\circledR}$ malgré un examen des voies aériennes qui était sans particularité sauf pour une ouverture de la bouche légèrement réduite et une grosse langue. L'intubation a été réalisée en insérant un MLA jetable de taille 5 dans les voies aériennes supérieures, en introduisant une FOB dans un AlC et en insérant ce FOB/AIC rassemblé dans la trachée au tra- vers du LMA, puis en enlevant le MLA et en passant ensuite un tube endotrachéal de taille régulière $(7,5 \mathrm{~mm})$ dans la trachée au-dessus de l'AlC.

Conclusion : Chez le patient présenté, l'AlC a été utilisé en remplacement d'autres méthodes d'intubation au travers d'un LMA régulier.

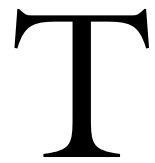

HERE are a wide variety of options for the management of the unexpected difficult intubation in patients under general anesthesia. These options include, but are not limited to, oral and nasal fibreoptic intubation, blind oral and nasal intubation, retrograde intubation, the use of a light wand (e.g., Trachlight ${ }^{\circledR}$, Rusch Inc., Duluth, GA, USA) or gum-elastic bougie, intubation through a Laryngeal Mask Airway ${ }^{\circledR}$ (LMA; LMA North America, San Diego, CA, USA ), and even the use of dental mirrors. ${ }^{1-6}$ In this report we describe the successful use of the Aintree intubation catheter ${ }^{\circledR}$ (AIC; Cook Critical Care, Bloomington, IN, USA), with the LMA and a fibreoptic bronchoscope (FOB) in a patient with an unexpected difficult airway.

\section{Case report}

The patient was a 38-yr-old $90 \mathrm{~kg}$ male scheduled for nasal endoscopy with ethmoidectomy. The procedure was to be performed under general anesthesia. The patient had an unclear history of difficult intubation with his first surgery, but stated: "I haven't had any problems

From the Department of General Anesthesiology, Cleveland Clinic Foundation, Cleveland, Ohio, USA.

Address correspondence to: Dr. D. John Doyle, Department of General Anesthesiology, Cleveland Clinic Foundation, 9500 Euclid

Avenue E31, Cleveland, Ohio 44195, USA. E-mail: doylej@ccf.org

Support was provided solely from institutional and/or departmental sources. The authors have no financial relationship with any of the manufacturers of any of the devices described in this case report.

Accepted for publication August 5, 2004.

Revision accepted February 18, 2005. 


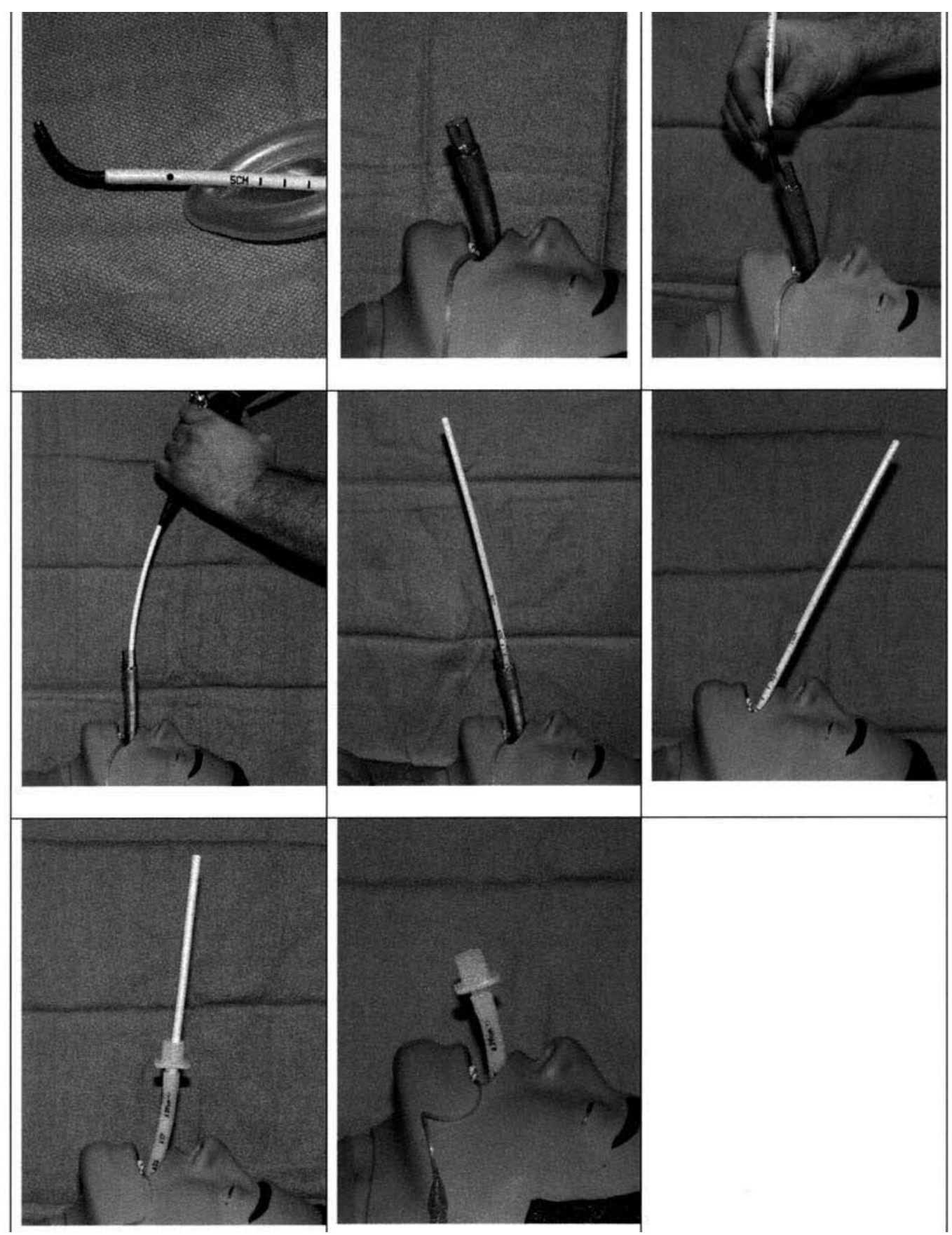

FIGURE Steps in carrying out the technique, illustrated in a left-to-right sequence

Step 1 (Preparation). Pass a fibreoptic bronchoscope (FOB) through the Aintree intubation catheter ${ }^{\circledR}$ (AIC), leaving a

2 to $3 \mathrm{~cm}$ tip of the FOB exposed. Then test that the assembly will pass easily through the laryngeal mask airway (LMA).

Step 2 Insert LMA in the usual manner.

Step 3 Insert FOB/AIC assembly into LMA.

Step 4 Advance FOB/AIC assembly well into the trachea under visual guidance. Note markings on the AIC relative to the patient's lips.

Step 5 Remove FOB while carefully holding the AIC in place.

Step 6 Remove LMA and check position of the AIC (see markings).

Step 7 Pass endotracheal tube (ETT) over the AIC into the trachea.

Step 8 Remove the AIC, leaving the ETT in place. 
with surgery since then". The patient's airway examination was unremarkable except for a slightly decreased mouth opening (about $4 \mathrm{~cm}$ ) and a large tongue.

Because of our favourable experience in using the GlideScope ${ }^{\circledR}$ video laryngoscope (GS) (Saturn Biomedical Systems, Burnaby, BC, Canada) in patients who were previously difficult to intubate, we decided to proceed using the $\mathrm{GS}^{7-9}$ under general anesthesia even though intubation was not expected to be difficult. Following pre-oxygenation, anesthesia was induced with propofol (200 $\mathrm{mg} i v)$, and succinylcholine (180 $\mathrm{mg} i v)$ was used to facilitate tracheal intubation. Mask ventilation was not difficult. We then attempted to intubate the trachea using the GS, but found that with the GS in place, the large tongue made it difficult to get enough remaining space in the oropharynx to successfully manipulate the endotracheal tube (ETT) into position, even though the laryngeal view was satisfactory. While consideration was given to using a gum elastic bougie or a Frova intubation introducer ${ }^{\circledR}$ (Cook Critical Care, Bloomington, IN, USA), at the time our experience with use of these adjuncts in conjunction with the GS was limited. We decided to resort to using direct laryngoscopy. Thus, the GS was abandoned in favour of a regular Macintosh size 4 laryngoscope, which was also unsuccessful because now the glottic structures could not be visualized at all (Cormack-Lehane grade 4 view).

Although we were still able to ventilate the patient by mask, we were concerned that further unsuccessful attempts at direct laryngoscopy could lead to airway trauma, converting a "cannot intubate" into a "cannot intubate, cannot ventilate" scenario. As a result we embarked on the following plan, illustrated in the Figure.

A size 5 disposable LMA (LMA Unique ${ }^{\circledR}$, LMA North America, San Diego, CA, USA) was placed, by which we were able to maintain ventilation easily. An AIC was then placed over a FOB, and both were then inserted without difficulty through the LMA into the patient's trachea. The FOB was then removed, followed by removal of the LMA, while taking care to maintain control of the proximal tip of the AIC at all times. Once the LMA was removed, a size 7.5 Parker Flex-Tip ${ }^{\mathrm{TM}}$ ETT (Parker Medical, Englewood, CO, USA ) was then "railroaded" over the AIC into the patient's airway. Following ETT cuff inflation and clinical/capnographic confirmation of the ETT position, the ETT was then secured. Upon completion of surgery the patient was extubated, and subsequently discharged home that day with information on obtaining a "difficult airway" MedicAlert ${ }^{\circledR}$ bracelet (MedicAlert Foundation International, Turlock, CA, USA).

After visualizing the larynx using the FOB we found no evidence of laryngeal trauma.

\section{Discussion}

The AIC is a disposable hollow ventilation/exchange bougie that allows a FOB to pass through. ${ }^{10,11}$ Specifically designed as an adjunct in intubating patients with a LMA in place, it has an internal diameter of $4.7 \mathrm{~mm}$, is $56 \mathrm{~cm}$ long, with a graduated scale on its outside. Its length covers the span of a standard fibreoptic scope, leaving the last $3 \mathrm{~cm}$ uncovered to allow directing of the scope. The catheter can be used to insert ETTs $7.0 \mathrm{~mm}$ or larger and comes with a Rapi-fit ${ }^{\circledR}$ connector (Cook Critical Care, Bloomington, IN, USA), to allow additional ventilation during intubation. ${ }^{10}$ Although authors have described its use in patients with normal airways ${ }^{10}$ as well as for intubating a patient through a cuffed oropharyngeal airway (COPA ${ }^{\circ}$; Mallinckrodt, Hazelwood, MO, USA) ${ }^{12}$ its use in a patient with a difficult airway has not yet been reported.

It should be noted that there are aperture bars on both the classic and disposable LMAs, and that these bars may sometimes obstruct the passage of an ETT. Thus, some individuals cut the aperture bars on disposable LMAs to eliminate this concern when passage of an ETT is planned. However, with our technique, it is not necessary to cut the aperture bars, as the AIC is substantially narrower than most ETTs. It should also be appreciated that the advantage of using the AIC over a bare FOB introduced via a LMA is that the catheter allows the LMA to be removed prior to ETT insertion.

Finally, while blind intubation using an intubating LMA (LMA Fastrach ${ }^{\circledR}$, LMA North America, San Diego, CA, USA) might have been possible, we are of the opinion that visually-based intubation techniques tend to have a higher success rate. We did not use an intubating LMA in this case because we wished to avoid using a blind technique.

In conclusion, the AIC provides an excellent alternative to the other methods for intubating through LMAs, such as a guidewire technique, ${ }^{13}$ using a small diameter ETT and pushing it blindly through the laryngeal aperture bars of the $\mathrm{LMA}^{14}$ or standard fibreoptic intubation through the LMA using a smaller diameter tube. ${ }^{15}$ The main advantage of airway management with the AIC is that it eliminates the need for changing a small diameter tube for a larger diameter tube along with the risks and costs incurred in doing so.

\section{References}

1 American Society of Anesthesiologists Task Force on Management of the Difficult Airway. Practice guidelines for management of the difficult airway. An updated report by the American Society of Anesthesiologists Task Force on management of the difficult airway. 
Anesthesiology 2003; 98: 1269-77.

2 Crosby ET, Cooper RM, Douglas MJ, et al. The unanticipated difficult airway with recommendations for management. Can J Anaesth 1998; 45: 757-76.

3 Kidd JF, Dyson A, Latto IP. Successful difficult intubation. Use of the gum elastic bougie. Anaesthesia 1988; 43: 437-8.

4 Rosenblatt WH, Wagner PJ, Ovassapian A, Kain ZN. Practice patterns in managing the difficult airway by anesthesiologists in the United States. Anesth Analg 1998; 87: 153-7.

5 Brimacombe JR, Brain AI, Berry AM. The Laryngeal Mask Airway: a Review and Practical Guide. London: WB Saunders; 1997.

6 Patil VU, Sopchak AM, Thomas PS. Use of a dental mirror as an aid to tracheal intubation in an infant (Letter). Anesthesiology 1993; 78: 619-20.

7 Cooper RM. Use of a new videolaryngoscope (GlideScope ${ }^{\circledR}$ ) in the management of a difficult airway. Can J Anesth 2003; 50: 611-3.

8 Agro F, Barzoi G, Montecchia F. Tracheal intubation using a Macintosh laryngoscope or a GlideScope ${ }^{\circledR}$ in 15 patients with cervical spine immobilization (Letter). Br J Anaesth 2003; 90: 705-6.

9 Doyle DJ, Zura A, Ramachandran $M$. Videolaryngoscopy in the management of the difficult airway (Letter). Can J Anesth 2004; 51: 95.

10 Atherton DP, O'Sullivan E, Lowe D, Charters P. A ventilation-exchange bougie for fibreoptic intubations with the laryngeal mask airway. Anaesthesia 1996; 51: 1123-6.

11 Logan S, Charters P. Laryngeal mask and fibreoptic tracheal intubation (Letter). Anaesthesia 1994; 49: 543-4.

12 Hawkins M. O'Sullivan E. Charters P. Fibreoptic intubation using the cuffed oropharyngeal airway and Aintree intubation catheter. Anaesthesia 1998; 53: 891-4.

13 Hasan $M A$, Black $A E$. A new technique for fibreoptic intubation in children. Anaesthesia 1994; 49: 1031-3.

14 Heath ML, Allagain J. Intubation through the laryngeal mask. A technique for unexpected difficult intubation. Anaesthesia 1991; 46: 545-8.

15 Benumof JL. Laryngeal mask airway and the ASA difficult airway algorithm. Anesthesiology 1996; 84: 686-99. 